\title{
4. Media ownership in Oceania: Three case studies in Fiji, Papua New Guinea and Tonga
}

\section{ABSTRACT}

The news media in Oceania are small but remarkably diverse and vigorous. Ownership ranges from large transnational corporations and robust local media companies, as in Fiji and Papua New Guinea, to local entrepreneurial and Government media interests, such as in Tonga and smaller South Pacific nations. News Corporation, through its South Pacific subsidiaries, owns the two largest English-language dailies, The Fiji Times and the PNG Post-Courier, while the Malaysian timber company Rimbunan Hijau is a major media investor in Papua New Guinea (The National) as well as having interests in New Zealand and South-East Asia. Australia's Channel Nine owns PNG's national TV broadcaster, EMTV, and New Zealand has played an important role in the development of Fiji Television. All three countries have had constitutional freedom of expression guarantees under assault in recent years and the role of the media in good governance has been an emerging theme. Three authors, prominent journalists (and, in the case of two, now also media educators), analyse the trends in their countries.

\section{FIJI}

SHAILENDRA SINGH

University of the South Pacific 
Fiji media, fuelled by technological advances and market demand, have grown dramatically since independence. The consumer now has a wider and more varied choice. But there are concerns about big business and Government ownership of the media. Equally disturbing are complaints that quantity has not meant quality.

$\mathrm{F}$ IJI'S MEDIA has come a long way since independence in 1970 when only one privately owned newspaper, The Fiji Times, and the stateowned radio station, the Fiji Broadcasting Commission (now Fiji Broadcasting Corporation), provided daily news coverage. Today, Fiji boasts a highly developed media industry compared to most other Pacific countries. Fiji now has three daily newspapers - Daily Post, Fiji Times and Fiji Sun; two monthly or bimonthly news magazines; a four-channel television station, several radio stations and major news websites.

But the growth of the media has been a double-edged sword with accompanying issues concerning media freedom, media ownership, cross media ownership and media consolidation. The Fiji Government and a handful of businessmen own much of the media. The potential and temptation to influence the media is great, and has been frequently attempted, most notably by Government.

While the audience has greater access to a more varied media, a common criticism is that quantity has not been accompanied by quality. This is the argument Government used to justify the introduction of a draft Media Council of Fiji Bill in May 2003. And it is a classic example of how the increase in the number of news organisations has not necessarily strengthened media freedom, but actually may have endangered it in a country where politicians and leaders are unused to intense scrutiny.

While the media and Government have, historically, been at odds, which is to be expected in a bona fide, functional democracy that Fiji claims to be, in recent years the level of antagonism has, on occasion, reached alarming levels. Even as the media grew bigger and more influential, the frequency and tempo of Government criticism increased.

Symptomatic of the Government's growing media-phobia is the lashing out against the media in recent years by ministers, Government senators and the Methodist Church hierarchy. The level of the attacks in Parliament, the Senate and public forums are unprecedented in Fiji. With the media under 
sustained pressure from three successive governments, there are concerns about the implications on media freedom. In a country where the racial nature of politics has rendered the mainly Indo-Fijian opposition in Parliament almost impotent, the media's watchdog role is too important to allow it to be compromised. Stapenhurst (2000) states that the media can act as a force against corruption in both tangible and intangible ways. Tangible ways include public exposure of dishonest bureaucrats leading to their impeachment, prosecution or resignation. Intangible ways result from the media fostering enlivened public debate, resulting in a heightened sense of accountability among politicians, public bodies and institutions that are inevitably the byproduct of a hard-hitting, independent news media. The media, to the discomfort of some people, are carrying out this function in Fiji.

\section{Background}

The Fiji media have played a significant role bringing to the public's attention issues of corruption. Not only have the media faced attacks for doing its job too well, but also for their alleged ethical and legal lapses. Fiji's largest and most influential daily newspaper is the Murdoch-owned The Fiji Times (average daily circulation 30,000). The other two dailies are the Fiji Governmentowned Daily Post (9000), and Fiji Sun (circulation unknown).

The Post and bimonthly news magazine, The Review, share a website, fijilive.com, while The Fiji Times launched its website this year. The Sun, launched in September 1999, is owned by a consortium of Indo-Fijian importers - C J Patel and Co Ltd and Vinod Patel and Co Ltd - and the Fiji Government-sponsored Fijian Holdings Ltd. Both the latter dailies do not have audited sales.

Apart from the Fiji Broadcasting Corporation (FBC), other broadcasters are Fiji Television Ltd and the private Communications (Fiji) Ltd (FM96) radio group, which began broadcasting in the year of the 1987 military coups. Fiji TV operates a free-to-air channel (Fiji One) and three-pay TV (SKY Sports, SKY Entertainment and SKY Plus) services. Transmission coverage includes the majority of Fiji's 830,000 population. Fiji One's nightly news service regularly attracts 60 per cent of the potential audience, an extremely high figure by international standards, according to the company's website (History of Fiji TV Ltd, 2004).

Fiji TV announced plans in early 2004 to invest \$F6 million into extending 
satellite coverage to the outer islands of the archipelago and to nearby countries. The satellite transmission will beam the free-to-air channel Fiji One and six pay-TV channels (Fiji TV spends $\$ 6 \mathrm{~m}$ to extend satellite coverage, 2004). The FBC, corporatised in 1998, plans to invest up to $\$ F 7$ million to shift to satellite technology to attain a nation-wide reach, introduce more radio stations and possibly foray into television (Broadcast Battle, 2004). CFL has also applied for a television broadcast licence.

With Fiji TV's Government-granted monopoly status coming to an end, an updated policy framework on the legislation of television was expected to be ready for Cabinet's approval by July. At least three international companies from China, Canada and Hawaii have applied for a licence to operate locally. Information Minister Simione Kaitani said the legislation would focus on the opening up of the television market (TV policy ready for cabinet approval, 2004).

One of Fiji's most prominent businessmen, Hari Punja, is another major stakeholder with 14 per cent shares in Fiji TV and a major stake in CFL. Punja's companies and others, such as C. J. Patel, not only wield influence in the boardroom, but are also the major advertisers, as is Government. The current range of news and views provided by the news media is wider and more varied than during any other era in Fiji's history. But critics say quantity has not ensured quality and the growth has been accompanied by complaints about declining standards. While there has been much debate and commentary on the co-relation between declining media standards and media freedom, concerns surrounding media and cross-media ownership and media consolidation by Government and big businesses have surfaced recently. The Pro Vice Chancellor of the University of the South Pacific, Konai Thaman (2004), notes that the globalisation of the media has not necessarily benefited indigenous people. Turning to Fiji, she highlighted the lack of TV programming in the indigenous Fijian language as an example of the marginalisation of indigenous cultures and peoples in Oceania by the mass media (Thaman, 2004: 1).

Sharon Bhagwan-Rolls, coordinator of femLink, a women's media advocacy NGO, is wary of the effects of the vigorous competition created by the commercial media environment. The media gets caught in the 'ratings hype' to attract advertising revenue to maintain operation and profitability. Because of this, civil society organisations are shut out, with consequences for national development and reconstruction (Bhagwan-Rolls, 2004: 6). 
The Government says a media policy to be implemented by the Information Ministry that will address some of the issues will be in place soon. But the Government is the most prominent cross-media operator in Fiji with interests across print, radio and television. Whether it adopts a policy that will dilute its presence in the news media remains to be seen. The precedent, however, suggests otherwise. The former Labour-Coalition Government led by deposed Prime Minister Mahendra Chaudhry, which throughout its one-year in office had constant clashes with the media, said it would discourage cross-media ownership and majority foreign ownership. Chaudhry (1999) said the Government would ensure that 'media ownership was spread as widely as possible so that no one organisation could buy in excess of a certain number of shares' (New Fiji Islands government continues attacks on media, 1999). But the Chaudhry Government refused to divest Daily Post shares despite criticising the purchase by its predecessors. It was ousted from power in the George Speight attempted coup in May 1999 and could not enact its media legislation. Likewise, the Qarase Government is refusing to let go of its Daily Post shares.

\section{Government-press-media-market relationships}

Governments, even in free societies, demonstrate a natural inclination towards media control. In Fiji, successive governments have shown such behavioural patterns. They have applied various forms of pressure - from criticism in Parliament and threats to introduce media legislation to withdrawing advertising from media companies or buying shares in them. Increased political and economic freedoms in Fiji plus advances in technology leading to a more educated populace fuelled an increase in demand for not only news, but of news free of Government influence and controls. Because the Government needs to be sensitive to public opinion, the Fiji public's desire to have a free media has acted as a bulwark against Government designs over the media. So much so that public pressure forced the Government to shelve the draconian Media Council of Fiji Bill that, if passed by Parliament, would have meant an end to media self-regulation. This is a playing out of the libertarian theory, which sees people as rational beings able to distinguish between truth and untruth. The people's demand that the press not only be free of Government influence and controls but actually keeps a check on Government, is an extension of the libertarian theory (Kunczik, 1988: 46-47).

In such a situation, public perceptions of a medium's credibility are crucial 
for survival. Any public perception of bias would hurt the credibility, and thus the marketability, of the medium. This could partly explain the Daily Post's failure to gain market share. It has been unable to shake off the tag of 'Government-owned newspaper' despite running critical stories about the Government. This was predicted by Leary (1999):

\begin{abstract}
When it comes to 'independence', two issues usually arise together: the need for independence and the need to be seen to be independent. Once public confidence about the independence of a newspaper is lost, it makes no difference whether editorial policy remains devoid of interference (Leary, 1999: 22).
\end{abstract}

In contrast, the Fiji Sun is performing better commercially even though arriving on the scene more than a decade later in 1999 . The privately owned CFL, to distinguish itself from the Government-owned Radio Fiji, paraphrased its news bulletin with the words 'independent radio station' after the 1987 military coup, when FBC news was heavily censored. CFL was aware that Fiji's news consumers had become more discerning and in order to win them over, it would have to prove its credibility. CFL clearly felt one way of doing this was by wearing its independent status on its sleeve.

Even the FBC, once completely under the Government's thumb, has been forced by market pressures to distance itself from Government. This was demonstrated by the chief executive officer Francis Herman's remark at a public forum that it was not for FBC to carry out the Government's public relations - that was the job of the Information Ministry (Herman, 2004).

\title{
The Government view
}

For all the advances that the Fiji media have made, the Government's view of the press seems rooted in the oldest of press theories, the authoritarian theory, which dates from the 16th century and derives from the state philosophy of absolutism - a top down approach. This theory holds that the press should advance government policy and service of the state. Towards this end, publishers are controlled by patents, licensing and censorship (Kunczik, 1988b: 46-47). Repeated attempts to regulate the media, and the utterances and actions of a succession of governments, government ministers and senators clearly show a trend towards an authoritarian-type situation where the press is 
an instrument of and subservient to the Government. When Information Minister Simione Kaitani (2002) did not agree with the coverage of the AfricaCaribbean-Pacific summit being held in Fiji, he used Parliament to accuse the press of supporting the opposition and destabilising the country (Fiji Media under fire over ACP, 2002).

Government senator Mitieli Balaunauca (2002) called journalists 'mad crazy loonies and stupid people' as well as 'agents of Satan'. Four days earlier, another senator, the Rev. Tomasi Kanailagi (2002), former head of the Methodist Church in Fiji, accused The Fiji Times and Fiji One of being 'agents of evil' for reporting lax accounting by the Methodists (Fiji journalists are 'mad, crazy loonies', says senator, 2002). Fiji's first Indo-Fijian Prime Minister, Mahendra Chaudhry, a champion of press freedom when he was Opposition Leader, became its harshest critic when his party formed Government:

The media in Fiji needs to take stock of how it is behaving and whether it is facing a crisis of ethics. My government has had occasion to be extremely disgusted by the antics of some elements in the media who have used the medium of the newspaper and television to further their own personal agendas to discredit the Government (New Fiji Islands government continues attacks on media, 1999).

Chaudhry, who had a long-running battle with The Fiji Times, lectured that a 'distorting' and 'lying' news media was not above the law and threatened to institute a 'swift justice' media tribunal (Chaudhry. 1999: 6-10). When he was ousted by the Speight rebellion, Chaudhry blamed the media, particularly The Fiji Times, for his Government's fall. The current Prime Minister, Laisenia Qarase, who labelled local journalists 'uncertain interviewers and poor verbal communicators having problems with accuracy' (Qarase, 2001), came closest to carrying out the threat of legislating the media with the introduction by his Government of the draft Media Bill. Widely condemned as draconian and unacceptable, the bill was grudgingly shelved in November 2003 by Information Minister Kaitani in the face of a 'No Media Bill' campaign mounted by the media. The intensity of the campaign forced Kaitani to complain in Parliament about being 'crucified afresh with my pound of flesh sought after by certain sections of our media outlets' (Kaitani, 2003).

The Government has used the argument of an unprofessional and poorly 
trained media to justify its push for media legislation. It says some of the media's reporting is dangerous in a multiethnic society such as Fiji, where racial and political tensions are always simmering below the surface. Commentators such as Shailendra Singh (2003) and Matt Wilson (2004) acknowledge that professional standards are lacking but add that a draconian media bill is not the answer. Genuine attempts to improve standards should start by addressing issues such as salaries, working conditions and training. Wilson said standards were 'slipping inexorably' and that the low pay of journalists was a cause (Media self-regulation under criticism, 2004). The Fiji Media Watch president, Father Larry Hannan, commented that standards would not improve unless working conditions - including pay - were improved (Fiji Media watch head calls for better pay, advocacy, 2003).

\section{Government control through proxies}

Control by Government through proxies is another concern. Fijian Holdings, a major Fiji Sun shareholder, is a private investment company set up by the Rabuka Government with a \$F20 million interest-free loan as a means of advancing Fijians in business. The loan was converted into a grant by the Qarase Government. Fijian Holdings has also acquired around three per cent Fiji TV shares. Another Fijian investment company, Yasana Holdings, was specifically created by the Qarase Government through the Fijian Affairs Board to buy Fiji TV shares on behalf of the 14 Fijian provinces. Yasana holds 51 per cent Fiji TV shares. Government also owns 15 per cent of TV through the Finance Ministry.

As a result of the crossover between its media investments and affirmative action programmes, Government has often found itself in conflict-of-interest situations. One example is the Government's introduction of a Bill in the June sitting of Parliament offering an exclusive retrospective tax exemption to Fiji TV backdated to 1994. Fiji TV says the exemption was promised by the Rabuka Government but never gazetted. Observers such as Aisake Casimira and Senator 'Atu Bain are outraged. Casimira, in a letter to The Fiji Times, questioned why Fiji TV, which made a profit of $\$ F 1.5$ million after tax in the last financial year, should be given special treatment (Casimira, 2004: 6). Bain (2004) said the tax exemption proposed by the Government could compromise the independence of Fiji TV. She asked: 
Is this an attempt by the SDL government to buy influence over this monopoly television company, particularly as it will face a national election in the near future? (Senator Bain criticises government tax deal for Fiji TV, 2004).

The Government had the numbers in Parliament to pass the Bill and Fiji TV is all but assured of the exemption. As observed by Bain, the move not only gives the Government leverage over Fiji TV, but a campaigning issue for the forthcoming elections. Ironically, Fiji TV has been singled out for some of the most scathing criticism by Government. Speaking at the opening of the 25th general conference of the Commonwealth Broadcasting Association in Nadi, Qarase blamed the 'rushing deluge of Westernisation' on Fiji's only commercial free-to-air television (PM condemns rushing deluge of Westernisation on Fiji TV, 2004).

Other ministers and senators have criticised Fiji TV, even singling out individual reporters. The underlying message seems to be that Fiji TV should consider that not only does a Government-sponsored company and a ministry cumulatively hold the majority (66 per cent) shares, but the fate of Fiji TV's monopoly status is also in Government's hands.

\section{Conclusion}

Fiji media have grown, fuelled by technological advances and demand. The consumer has a wider and more varied choice. But there are concerns about big business and Government ownership of the media. Government consternation with the media has increased with the growth of the media, resulting in attempts by various governments to influence the media. Intense competition combined with the reporters' and editors' journalistic instincts and public support have counteracted the Fiji Government's efforts to control the media. But the media cannot rely on public goodwill alone. It needs to address public concerns about quality and get its own house in order also. Otherwise there will be consequences for media freedom. 


\title{
PAPUA NEW GUINEA
}

\author{
KEVIN PAMBA
}

Divine Word University, Madang

Media organisations - mostly foreign-owned - have yet to make Papua New Guineans really feel and appreciate their national identity and the role of the media in Oceania's largest democracy. And the media has done little to reinvest in critical areas such as investigative journalism, so vital in a corruption-rife country.

$\mathrm{T}$

HE MEDIA in Papua New Guinea is predominantly foreign-owned and controlled. No effort has been made to promote local ownership of the Communication Policy of 1994 recognises the need to support local ownership. Politicians have often criticised and threatened to control the media for reporting the country's chronic crime and corruption problems along with other negative news.

The politicians have a tendency to blame the media for chasing away investors and tourists through reporting about negative stories such as those about crime and corruption. Some of the claims against the media have merit. With every new accusation, the media have often come out as the winners with a massive public and mostly non-governmental support.

In their claims against the media, the politicians have not raised one finger to support local media ownership as a means to a better and representative coverage of the country.

\section{Lack of political support}

Political will to support local media ownership is virtually non-existent and this is in spite of the 1994 policy objective to encourage local ownership. It is a policy that was drawn up to underpin the organisation and development of the information and communication sector. But political apathy has led to the policy not being formally adopted by any government since then.

The draft policy saw ownership this way: 
Ownership means control. Because the various forms of media can have such a powerful influence and impact on people, national sovereignty and cultural autonomy are at stake. For this reason, it is important that Papua New Guineans have effective control over all types of media at every level - local, regional and national.

\section{Call for media support in training}

One former Prime Minister, Bill Skate, recognised ownership as a critical aspect of media operations in 1999. Skate felt that the foreign companies that owned media companies should plough something back into the country through areas such as training. Presenting a paper as the keynote speaker at the opening of the World Media Freedom Day workshop in Port Moresby on 3 May 1999, Skate said:

It disappoints me when I see foreign companies, who own media outlets in Papua New Guinea, ignore media and journalist training in our nation. The companies earn money from our nation but do not put sufficient money back into training and developing our journalists. I am calling on Channel Nine in Australia[owners of PNG's EMTV] to help your television station in Papua New Guinea by providing real training for your journalists. Teach your people in Papua New Guinea with the thoroughness you provide for your staff in Australia (quoted in Weber, 1999).

Industry-supported training remains a critical issue in PNG with present approaches being ad hoc. Currently, the media industry has ad hoc arrangements with in-house training and on-training partnerships with the two journalism training programmes at the University of Papua New Guinea in Port Moresby and Divine Word University in Madang. Nothing concrete or long-term exists to forge training partnerships between the industry and the media education institutions of the country.

Training, although it is emphasised in the draft information and communication policy, has not provided the impetus for the various stakeholders to take notice. The current Opposition Leader, Peter O'Neill, was critical of the support journalists get from the media organisations that employ them. O'Neill criticised the employment conditions of journalists, which he claimed affected the quality of the journalism, which he described as low (News reporting narrow, lacks depth, 2004). 
In a statement carried by the Post-Courier newspaper (23 September 2004), O'Neill is quoted as saying 'media organisations in the country must get their act together in order to make the industry more vibrant, professional and responsive to the ever-growing public demands of PNG's development needs'. O'Neill made the remarks when welcoming the reappointment of Frank Senge Kolma, one of the country's most accomplished journalists, as editor-in-chief of the rival National newspaper. He was quoted as expressing widely shared concerns about the need for the media to create a 'more conducive work environment' for journalists and other professionals:

Poorly paid journalists can fall easy prey to unscrupulous politicians and businessmen who are bent on having their way. Improved working conditions for journalists, including a salary scale on par with their overseas counterparts, is not an outrageous proposition if the industry's role, reputation and future viability are to be enhanced and the nation's collective good assured. Nor is it far-fetched to expect media organisations to devote new investments to expanding the scope and depth of their news coverage, including proper development of investigative brand of journalism in PNG. We all know there is a lot more going on in the country than what actually makes it to print or the airwaves these days (News reporting narrow, lacksdepth, 2004).

\section{AusAID report uncritical of foreign ownership}

An Australian Government-funded assessment of the media sector by the PNG Media for Development Initiative (2004) is critical of the draft policy and recommends that it be updated. The report notes that although the Government has never adopted the draft policy, it is still being used by organisations such as the Office of Information and Communication - the body tasked to oversee the media sector (which was recently upgraded to 'department' status). According to the AusAID report: 'The policy, however, is in need of an update to take into account developments in information technology. It is possible that UNDP may provide assistance for this.'

The report, though, does well in identifying the weaknesses and strengths of the media and suggests ways of improvement. But it does not regard ownership as critical to the issues it raises about content, access and the viable existence of media organisations in the country. The report, for example, does not recognise that the most influential media outlets in the country are foreign- 
owned and controlled. The report does not explore the relationship between ownership and content.

Instead it makes sweeping claims that the media sector in the country promoted national developmental aspirations and had the potential to do better. While it does identify weaknesses in programme format and content of, particularly, the broadcast media, it does not make any link to the objectives of the owners - that their profit motive overrides any consideration for improvement in equity.

\section{Profit motive prevails}

The profit-motive of the commercial media prevails and expansion and content tends to be determined by this (Rooney et al, 2004). The only television station, the Australian-owned, EMTV, for instance, does not have any regional offices apart from its main office and studios in the national capital, Port Moresby. This is despite EMTV, which is owned by Australian media mogul Kerry Packer, existing as a monopoly since its establishment in 1987. Seventeen years later and EMTV has not publicly announced a profit and its coverage is still restricted to the main towns and small centres with economic capacity such as the mining towns of Tabubil and Porgera.

Recently though, EMTV has boosted its services with an arrangement that has provided itself literally free coverage of several towns and an increase in audience base in at least two provinces, Enga and Southern Highlands. In rather ill-advised decisions, politicians in the two provinces have agreed to pay EMTV hundreds of thousands of kina to pay for transmission to selected towns there. In the Southern Highlands, for example, the provincial governor, Hami Yawari, recently paid 100,000 kina to EMTV to ensure the commercial network is beamed to Ialibu, a very small outstation of some 2000 people with surrounding villages of more than 40,000 people with no electricity to power any TV set they may have. The governor of this province has announced he will continue to hand out similar amounts to EMTV to be allowed to broadcast to parts of his province. In these decisions, ownership and relevance of the content has not been a considered by the politician - or whether it is appropriate for politicians to pay for the expansion of a commercial television station.

The oldest and largest circulating national daily newspaper,Post-Courier, is majority-owned and managed by Australians. The Post-Courier is part of Rupert Murdoch's News Corporation group with minority shares held by PNG 
interests. The second national daily newspaper, The National, is owned by the Malaysia conglomerate, Rimbunan Hijau, which has large logging interests in Papua New Guinea and the Pacific region.

While the public radio broadcaster, National Broadcasting Corporation, enjoys the position of being the only media organisation to reach a majority of the people on short wave, several foreign and locally owned commercial and community FM radio stations have appeared on the broadcast scene in the past 10 years. But most of the stations target the economically well-off urban audience. The increase in radio stations has challenged the privileged position of the NBC along with its spin-off commercial station, Kalang FM. Kalang FM has since been taken over by Telikom PNG - the state-owned telecommunications company - after NBC failed to pay the arrears and the radio station now operates as FM100.

While the radio sector has grown dramatically, no new newspapers or television stations have opened. This can be attributed to the lack of political interest and the poor economic conditions of the country. The Independent newspaper, once the influential Times of Papua New Guinea weekly newspaper, folded in 2003 due to an inability to remain operational under a rising cost structure. The departure of The Independent left its Tok Pisin sister paper, Wantok, alone to serve the weekly in-depth and analytical news and features market, although it finds it difficult to perform in this way and opts to imitate the deadline-driven reporting styles of the daily newspaper. The Independent and Wantok titles are part of the Word Publishing group, which is owned by the mainstream churches, Anglican, Catholic, Lutheran and United Church (Methodist).

Some consolation was provided when The National newspaper announced last year that it was setting up a regional printing press in PNG's second largest city, Lae, to serve the northern half of the country. It initially appointed more staff and increased office space there. This plan is yet to get off the ground.

\section{Conclusion}

One feels a little apprehensive and withdrawn when politicians in particular, complain about the media in Papua New Guinea these days. There is hardly any thought given to making a link between media content and ownership by the leaders of this country. Concerns are few and far between and no effort has been made to support local ownership. When leaders and some members of the 
public are very vocal about the media it is usually against what they see as negative portrayal of the country by news reports. They often complain that the reporting of the country's notorious crime and corruption problem prevents investors and tourists from coming to the country.

They tend to assume that the mainstream media in its current set up can play the role of investment promoter, tourism agent and a megaphone for Government initiatives in national development. Little effort is made to define these responsibilities with the different strands of media such as the community media, mainstream media, civic (public or development) journalism (media) and so on. One thing political leaders and others have not acknowledged is that Papua New Guinea is a large country, compared to other Pacific island nations, with a rapidly growing population and dynamic changes taking place. With such dynamism, come obvious changes in attitudes and demands, including expectations of the media. Among the expectations would be those of national identity and awareness fostered mostly by consciously aware media.

The present media organisations - with most being foreign-owned - have yet to make Papua New Guineans really feel and appreciate who they are and what they are getting from the media. And the media has done little to reinvest in critical areas such as investigative journalism, so vital in a corruption-rife country. 


\section{TONGA}

KALAFI MOALA

Publisher of Taimi 'o Tonga

Tonga's most popular newspaper was banned following a series of unconstitutional laws aimed at repressing freedom of expression. A major constitutional challenge was heard in the Supreme Court in Nuku' alofa in September 2004. The court ruled on 8 October 2004 that an amended freedom of speech clause was unconstitutional and that the so-called media and newspaper laws were illegal.

7 ROM THE outset, Tonga's amendment of its Constitution regarding freedom of speech and press freedom was unconstitutional. It was done to enable legislation outlawing newspapers the kingdom's Government deemed critical, insensitive, seditious, and with an 'unacceptable standard' of journalism - whatever that means.

Even though the new laws - the Media Operators Act 2003, Newspaper Act 2003 and Act of Constitution of Tonga (Amendment) Act 2003 - targeted the Taimi 'o Tonga newspaper, they ended up affecting other newspapers or print media sometimes critical of Government policies and practice. In my view, the whole exercise was caused by an absurd childishness. History will confirm this.

On 26 February 2003, the Minister of Finance, Siosiua 'Utoikamanu, who is also in charge of Customs, informed us that Taimi 'o Tonga was 'a prohibited import'. His letter read:

You are hereby given notice, that pursuant to section 34 of the Customs \& Excise Act (Cap 67), the publication Taimi 'o Tonga is as of the date of this letter a prohibited import into the Kingdom of Tonga.

This was the first ban. Further clarification came by fax the same day, saying:

The decision conveyed to you by notice prohibiting the importation of the Taimi 'o Tonga... stands. That decision shall stand until revoked. As from the date of your receipt of the notice, Taimi 'o Tonga is a prohibited import. The reasons for the decision made are according to Government

62 PACIFIC JOURNALISM REVIEW 10 (2) 2004 
policy and specifically that:

it is a foreign paper owned and published by a foreigner;

it is a foreign concern with a political agenda;

the continuous standard of journalism is unacceptable.

The said decision shall be enforced.

Then 'Utoikamanu as Chief Commissioner of Revenue, issued the following declaration the next day:

In exercise of the powers vested by section $35 \ldots$ the Chief Commissioner of Revenue hereby declares that all editions, volumes or part thereof of the newspaper Taimi 'o Tonga to be [sic] seditious or advocating violence, lawlessness or disorder.

In a letter on 7 March 2003, the Minister of Justice and Attorney-General, 'Aisea Taumoepeau, issued another clarification to an order by the Privy Council prohibiting 'the importation of any issue of the publication of Taimi 'o Tonga or part thereof'. His reasons to the order-in-council (the Privy Council is Cabinet meeting with the King presiding) were:

The matters considered by His Majesty in Council included the following:

The newspaper is involved in anti-attitude [sic] and propaganda against the Monarchy and the Tongan Government. It is committed to the removal of the present Institution of Government.

The newspaper has caused considerable disaster, confusion and disaffection against the Monarch and the Government.

Over a period of time the newspaper produced articles on changes to the system of Government in this country. It has caused disaffection amongst the people.

The newspaper published seditious materials.

The newspaper is advocating and inciting violence, lawlessness and disorder.

Complaints from individuals and groups, and a report from the Special Branch of the Ministry of Police, were received.

The standard of journalism is unacceptable.

The newspaper is foreign-owned and is published overseas and imported into the Kingdom. 
While the newspaper is now published twice-weekly in Auckland, New Zealand, for technical reasons (we distribute in New Zealand, Australia, and the United States), it was produced in Tonga for the first five years of its life (see Moala, 2002). The Taimi is published in the Tongan language, all its journalists are Tongans, it was founded in Tonga - by me, a Tongan. The only reason the Tongan Government has labelled it 'foreign' is because I - the newspaper's owner and publisher - am Tongan-born with full-blooded Tongan ancestry, and also happen to be a naturalised American citizen.

It is the content of some of our newspaper's coverage which Tonga's ruling elite regard as odious, not the nationality of my passport. We took the Tongan government to court over its ban. After a Supreme Court hearing of several days where Chief Justice Gordon Ward presided, his judgement on 4 April 2003 ruled the ban was 'unlawful and invalid'. He ordered the quashing of each ban issued by the Government.

On the same day, the Privy Council passed 'an Ordinance for the protection of the King, Royal Family, Government and People of this Kingdom from abuse of Press Freedom'. The King and his council ignored the Supreme Court's judgement, instead issuing an ordinance making it 'unlawful for any person to publish, sell or offer for sale, distribute, copy or reproduce, possess, or import either the Taimi 'o Tonga newspaper or Lali Media Ltd publications'.

The King and his council's order reimposed the earlier bans ruled unlawful and invalid by the court. At the hearing, the Government had produced eight articles from various issues of the Taimi which it deemed as seditious, inciting violence, and as causing disaffection for the King.

Court records show how ridiculous it was to use such articles to argue the Government's case. None could be interpreted in any way as seditious or inciting violence. Two cited articles comprised interviews with a widely respected Free Wesleyan minister. Another was an interview with Tonga's leading academic, Professor 'I Futa Helu.

Tonga's leaders apparently took umbrage over one of my columns in which I criticised the inconsistency in the King's decision to open a cigarette factory in Tonga despite his 12-year campaign against smoking. Other articles included two letters to the editor, an editorial by our editor, and news coverage of a group, opposed to democracy, who urged people to vote for either Pohiva or the King during the 2002 Parliamentary election. After losing the Supreme 
Court case, the Government appealed to the Appeals Court - and lost again. The kingdom's highest court had upheld the Chief Justice's judgment.

Meanwhile, an attack was launched in the Tongan media against the Chief Justice by the Kotoa Movement whose patron is the King's only daughter, Princess Pilolevu Tuita. That movement's newspaper, Tonga Star, makes no bones about its support for the royal family. The Government chose not to come to the Chief Justice's defence. Its silence spoke volumes about its displeasure at his ruling. It may even have been guilty of wanting to discredit the Chief Justice.

As claims were filed against the Government for the unlawful banning and financial losses suffered by the Taimi, the Government hatched a plan to change the ground rules to amend the Constitution's freedom of speech clause which has enshrined freedom of the press in Tonga for more than 120 years. It was also putting together rather haphazardly unlawful and unconstitutional newspaper laws. The Constitution was then amended and restrictions on freedom of speech and on press freedom imposed.

The Government erected 'biased boundaries' with a 'cultural tradition' tag on them. The result is that every Tongan is supposed to stay within the narrow confines of those boundaries while the ruling elite is not confined by these same boundaries. The Government has used the cover of cultural traditions, the establishment of 'responsible' media, and whatever else it needs to conceal its wish not to be questioned or criticised.

It is also reacting in fear knowing full well that because of its years of economic mismanagement, combined with a series of embarrassing local and international scandals, it no longer deserves the trust or loyalty of the people of Tonga.

Tonga's Prime Minister, Prince Lavaka 'Ulukalala Ata, told a Hawai'ian reporter last year that 'they have gone too far'. He was referring to us.

What does he mean by 'going too far'? Is raising issues of good governance, accountability, and transparency going too far? Is exposing corruption, violation of human rights, and discrimination going too far? Can anyone ever go too far in doing what is right?

The Government has taken away the rights of more than 40,000 regular readers in Tonga to read a newspaper they obviously like. It insults the intelligence of ordinary Tongans by claiming it does not know what is good or bad for them and therefore needs to regulate what it (the Government) needs people to read or not read. 
It also says Tongans cannot speak freely and express their views or opinions. So here we have a country where the people do not have the right to choose who should govern them nor how they should be governed and their rights to free speech and freedom of expression have been taken away.

The Government's actions in amending the Constitution and legislating newspapers may well have been driven by a vengeful and malicious resolve to ban the Taimi 'o Tonga in Tonga for good. These irresponsible actions have hurt the people of Tonga and highlighted Tonga's authoritarian form of government.

If history is a guide, the time will come when the people will reject such authoritarianism one way or another. A major constitutional challenge was heard in the Supreme Court in Nuku'alofa in early September 2004. This was a challenge claiming that what the Government and the Legislative Assembly in particular have done in amending the freedom of speech clause was not only unconstitutional, but that the so-called media and newspaper laws should be declared invalid.

The court declared the media laws unconstitutional. However, the kingdom's ruling regime is taking the small island nation on a dangerous pathway that can only come to a dead-end of economic and political ruin.

\section{References:}

AusAID. (2004). PNG Media for Development Draft Design Document, April.

Bain A. (2004). Senator Bain criticises government tax deal for Fiji TV. May 16. www.flp.org.fj/n040516.htm (Accessed 20 June 2004)

Bhagwan-Rolls S. (2002, February 21). Media in Fiji. The Fiji Times. p 6.

Broadcast Battle. (2003, November 1). The Review, p 1.

Casimira, A. (2004, June 22). Fiji TV tax break. The Fiji Times, p 9.

Chaudhry, M. (1999). Address at the launching of the [Fiji] Media Council General Code of Ethics and Practice, Suva, October 26, pp 6-10.

Clark, A. (2000). Trouble in Paradise: A Study of Media Censorship in the South Pacific, p 21.

www.beaweb.org/bea2000/papers/clark.pdf (Accessed June 8)

Fiji journalists are 'mad, crazy loonies', says senator. (2002, August 29). Wansolwara Online. www.usp.ac.fj/journ/docs/news/wansolnews/2002/2002august/ wansol2908022.html (Accessed 18 June 2004).

Fiji PM launches another attack on local media. (2004, February 21). Pacific Media Watch. www.pmw.c2o.org/2004/fiji4314.html (Accessed 18 June 2004).

Fiji media under fire over ACP (2002, July 22). Pacific Media Watch. www.asiapac.org.fj/cafepacific/resources/aspac/fiji3710.html (Accessed June 18).

66 PACIFIC JOURNALISM REVIEW 10 (2) 2004 
Fiji Media Watch head calls for better pay, advocacy. (2003, August 19). Wansolwara Online.

www.usp.ac.fj/journ/docs/news/wansolnews/2003/2003 August/ wansol1908031.html (Accessed 18 June 2004).

Fiji TV spends $\$ 6 \mathrm{~m}$ to extend satellite coverage. (2004, February 19) Wansolwara Online.

www.usp.ac.fj/journ/docs/news/wansolnews/2004/feb/wansol1902041.html (Accessed June 10, 2004)

Herman F. (2004, May 4). Media Freedom Day seminar panellist. University of the South Pacific, Suva.

History of Fiji TV. (2004). (Accessed 20 June 2004). www.fijitv.com.fj

Information and Communication Policy of Papua New Guinea. (1994). Port Moresby: Government Printer.

Kaitani, S. (2003, November 25). Address on the 2004 national budget. http://beta.fiji.gov.fj/publish/page_1631.shtml (Accessed June 23, 2004).

Kamea, J. (1999). The Daily Post sale. Pacific Journalism Review. 5(1): 9-14.

Kunczik, M. ( 1998). Concepts of journalism - North and South. Bonn: Media and Communications Department, Friedrich-Ebert-Stiftung, pp 46-47.

Leary, I. (1999). Is freedom of the Pacific press really free? Pacific Journalism Review, 5(1): 21-24.

Media self-regulation under criticism. (2004, May 5). Wansolwara Online. http://www.usp.ac.fj/journ/wansolnews/2004/may/wansol0505041.html (Accessed 10 June 2004)

Moala, K. (2002). Island Kingdom Strikes Back: The Story of an Independent island Newspaper-Taimi 'o Tonga. Auckland: Pacmedia Publishers.

Nadkarni, D. (2003, September) Pacific media: the threat within. Wansolwara, p 12. Naidu, R. (1999). Taxpayers in business. Pacific Journalism Review, 5(1): 16-18.

New Fiji Islands government continues attacks on media. (1999, March 7) PINANews Online. $\quad$ www.pinanius.org/archives/1999/07031999.html (Accessed 2 June 2004).

News reporting narrow, lacks depth (2004, September 23). Post-Courier.

PM condemns rushing deluge of Westernisation on Fiji TV. (2004, February 17).

Wansolwara Online.

www.usp.ac.fj/journ/wansolnews/2004/feb/wansol1702041.html

(Accessed 15 June 2004)

Qarase L. (2001), January 24). PM clips media. The Fiji Sun, p 3.

Richardson, M. (2002, November).Sun looks abroad for skills, mentors. Wansolwara, p 6.

Rooney Dick et al. (2004). A country failed by its media: A case study of Papua New Guinea. Seminar paper at AMIC Conference, Bangkok, Thailand.

Singh, S. (2002, November). Of croaking toads, liars and ratbags. Wansolwara, p 6. Singh, V. (1999). Post mortem on a bad deal. Pacific Journalism Review, 5(1): 25-27. 


\section{MEDIA OWNERSHIP AND DEMOCRACY}

Shafer, R. (1992). Constraints on Practising Ethical journalism in Developing Nations: A Philippine Case Study. Media Asia, 19(3):123-30.

Stapenhurst R. (2000). The media's role in curbing corruption: World Bank Institute Working papers, World Bank, p 4.

Swann, O. (2003, August 2). Fiji journalists deserve better pay, more respect. Wansolwara, www.usp.ac.fj/journ/docs/news/wansolnews/2002/2002Auugust/ wansol0208021..html

(Accessed 11 January 2004)

Thaman, K. (2004). The media role in supporting nation-building and managing conflicts. Media Freedom Day address, May 4. University of the South Pacific, Suva, $\mathrm{p} 1$.

The trouble with scandal. (1994, May). The Review, p 22.

Weber Joe (ed.) (1999). A Fragile Freedom: Challenges facing the media in Papua New Guinea. Madang: DWU Press.

Shailendra Singh, is former editor of The Review news magazine and is now lecturer in journalism with the Department of Literature and Language at the University of the South Pacific; Kevin Pamba is a columnist with The National in Port Moresby and a lecturer in journalism at Divine Word University, Madang, PNG; and Kalafi Moala is publisher of Taimi 'o Tonga, chair of the Pacific Islands Media Association (PIMA) and owner of the Auckland-based Lali Media Group.

singh_sh@usp.ac.fj

kpamba@dwu.ac.pg

k.moala@clear.net.nz 